\title{
JOURNAL.RU
}

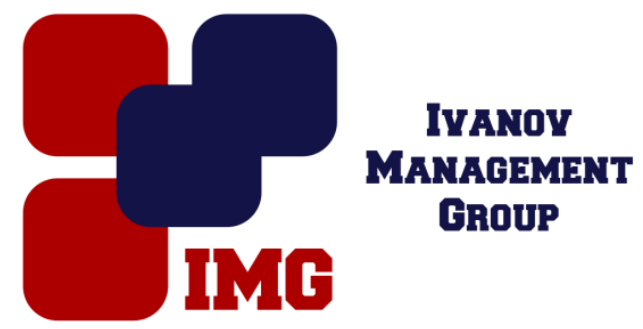

Чеверикина Е.А., Фатина М.Л.

Институт педагогики, психологии и сочиальных проблем Казань, Россия

doi: 10.18411/1j-31-07-2017-11

idsp 000001:1j-31-07-2017-11

\section{Агрессивность как составляющая феноменов психологического насилия и психотерроризма}

\section{Аннотация}

Статья посвящена осмыслению феноменов психологического насилия и психотерроризма в рамках социальной психологии, которые коренятся в психических, психологических, социально-психологических особенностях личности, проявляются в различных сферах ее жизнедеятельности и являются пусковым механизмом готовности к деструктивной, в том числе экстремистской деятельности. Рассматривается агрессия как способ поведения и лежащая в ее основе агрессивность как личностное свойство, которые являются важным элементом для понимания феноменологии психологического насилия и психотерроризма. Приводятся результаты эмпирического исследования проявления психологического насилия и психотерроризма в межличностном общении подростков.

Ключевые слова: психотерроризм, психологическое насилие, агрессия, агрессивность, экстремистская и террористическая деятельность.

Современный экстремизм и терроризм как крайняя форма его проявления рассматривается в основном как явно выраженные агрессивные насильственные акты одного человека или группы лиц с целью причинения непоправимого и массового вреда обществу и привлечения внимания общественности к своим политическим, социальным, религиозным взглядам и убеждениям через совершение одиночных или массовых террористических актов[Ошибка! 
Источник ссылки не найден.].Но очень часто упускается из сферы изучения данной тематики то, что в повседневной обыденной жизни люди сталкиваются с разовыми или перманентными актами насилия, агрессии, давления, унижения, оскорблений и т.д. со стороны людей из ближайшего окружения (члены семьи, коллеги по учебе или работе, знакомые и т.д.), которые вызывают у них чувство дискомфорта, страха, паники. То есть можно говорить о существовании индивидуального, межличностного психологического насилия и психотерроризма как одной из разновидностей экстремисткой и террористической деятельности.

В современной науке нет определения понятия «психотерроризм», этот феномен рассматривается в основном с точки зрения семейных отношений: давление мужа на жену, жены на мужа, родителей на детей и наоборот [Ошибка! Источник ссылки не найден.]. В рамках зарубежной и отечественной трудовой и юридической психологии рассматриваются проявления психотерроризма в трудовом коллективе (моббинга, буллинга как негативного коммуникативного воздействия, целенаправленного нанесения вреда человеку на работе [Ошибка! Источник ссылки не найден.]). Широко изучаются, особенно за рубежом, проблемы кибербуллинга как агрессивного умышленного действия с использованием электронных форм взаимодействия (в основном с помощью интернета), повторяющегося неоднократно в течение продолжительного времени в адрес жертвы, которой в данной ситуации очень трудно себя защитить [Ошибка! Источник ссылки не найден.].

На наш взгляд, явление психотерроризма, тесно связанное с психологическим насилием, гораздо более широкое и глубокое, коренится в психических, психологических, социально-психологических особенностях личности, проявляется в различных сферах ее жизнедеятельности и является пусковым механизмом готовности к вовлечению в экстремистскую и террористическую деятельность. Если исходить из того ряда понятий, которые связываются с психотерроризмом, то данное явление можно описать как прямое или косвенное индивидуальное или групповое давление на другого человека или группу лиц, подразумевающее явную или скрытую агрессию, с целью принуждения к совершению желательных (сознательно или неосознанно) для оказывающей это давление стороны действий, подчинение своей воле.Психотеррористическое воздействие выражается словами или поведением, явно не наносящими вред или несущими угрозу человеку, но оказывающими сильное негативное влияние на его психическое состояние, приводящими к 
фрустрации, обостряющими чувства дискомфорта, страха, повышающими тревожность.

Агрессия как способ поведения и лежащая в ее основе агрессивность как личностное свойство является важным элементом для понимания феноменологии психологического насилия и психотерроризма. В психотеррористическом акте ее проявление амбивалентно - она обнаруживается как со стороны психотеррориста по отношению к жертве (злость, ненависть, стремление унизить и т.д.), так и со стороны жертвы по отношению к психотеррористу (например, эффект «крысы, загнанной в угол»).

Агрессивность - устойчивое стремление индивида нанести другому человеку физический или психотравмирующий вред, ущерб. Агрессия может быть фрустрационной (агрессивность против тех, кто препятствует достижению значимых целей), импульсивной и аффективной. Она может быть также умышленной и инструментальной (когда агрессия используется лишь как средство достижения цели). Агрессивность как устойчивая черта формируется в неблагоприятных условиях психического развития личности, является показателем несформированности у нее социальной идентификации, десоциализированности и общимих дефектов в психической саморегуляции индивида[Ошибка! Источник ссылки не найден.].

Агрессивность - свойство личности, заключающееся в готовности и предпочтении использования насильственных средств для реализации своих целей. Агрессия - проявление агрессивности в деструктивных действиях, целью которых является нанесение вреда тому или иному лицу. Агрессивность у различных лиц может иметь различную степень выраженности - от почти полного отсутствия до предельного развития [Ошибка! Источник ссылки не найден.]. Вероятно, гармонически развитая личность должна обладать определенной степенью агрессивности. Потребности индивидуального развития и общественной практики должны формировать в людях способность к устранению препятствий, а подчас и к физическому преодолению того, что противодействует этому процессу. Полное отсутствие агрессивности приводит к податливости, неспособности занять активную жизненную позицию. Вместе с тем чрезмерное развитие агрессивности по типу акцентуации начинает определять весь облик личности, превращает ее в конфликтную, неспособную на социальную кооперацию, а в своем крайнем выражении является патологией (социальной и клинической): агрессия утрачивает рационально-избирательную направленность и становится привычным способом поведения, проявляясь в 
неоправданной враждебности, злобности, жестокости, негативизме [Ошибка! Источник ссылки не найден.].

Агрессивные проявления могут являться:средством достижения определенной цели,способом психологической разрядки, замещения блокированной потребности,самоцелью,способом удовлетворения потребности в самореализации и самоутверждении.

Таким образом, агрессивность человека неоднородна, варьирует от слабой до крайней степени, различна по своей модальности и назначению. Можно выделить параметры агрессивности различной модальности [Ошибка! Источник ссылки не найден.], отличающиеся:

1. интенсивностью агрессии, ее жестокостью;

2. направленностью на конкретное лицо либо вообще на всех людей;

3. ситуативностью или устойчивостью агрессивных тенденций личности.

Условно можно выделить следующие разновидности поведения с точки зрения агрессивности [Ошибка! Источник ссылки не найден.]:

1. антиагрессивность - негативное отношение к любым агрессивным проявлениям человека, который всегда старается примириться с людьми, считает для себя невозможным бить слабого, женщину, детей, калеку; в случае конфликта считает, что лучше уйти, стерпеть или обратиться в милицию, обороняется лишь при явном физическом нападении;

2. интринсивная агрессия, мотивированная удовлетворением, получаемым от выполнения условно-агрессивной деятельности (игры, борьба, соревнования), не имеющая цели причинения вреда. Таким образом, спорт является социально приемлемой формой проявления агрессивных тенденций человека, своеобразной разрядкой агрессии, а также формой самоутверждения, повышения социального статуса и получения материальных благ (для профессиональных спортсменов);

3. агрессивность недифференцированная - несильное проявление агрессии, выражающееся в раздражительности и скандалах по любому поводу и с самыми различными людьми, во вспыльчивости, резкости, грубости. Но эти люди могут дойти до физической агрессии и даже преступления на семейно-бытовой почве; 
4. агрессивность локальная, или импульсивная, - агрессия проявляется как непосредственная реакция на ситуацию конфликта, человек может словесно оскорбить противника (вербальная агрессия), но допускает и физические средства агрессии, может ударить, избить и т.п. Степень общего раздражения выражена меньше, чем в предыдущем подтипе;

5. условная, инструментальная агрессия, связанная с самоутверждением, например в мальчишеской возне;

6. агрессивность враждебная - устойчивые эмоции злости, ненависти, зависти, человек свою враждебность проявляет открыто, но не стремится к столкновению сторон, реальная физическая агрессия может быть и не очень выраженной. Ненависть может быть направлена на конкретное лицо, посторонние незнакомые люди могут вызывать у такого человека раздражение и злобу без всякого повода. Возникает желание унизить другого человека, чувствуя к нему презрение и ненависть, но этим добиться уважения окружающих. В драках хладнокровен, в случае победы вспоминает драку с удовольствием. Свою агрессию может вначале сдерживать, а потом мстит (разными способами: клеветой, интригами, физической агрессией). В случае перевеса сил и вероятности безнаказанности может дойти до убийства. В целом к людям относится враждебно;

7. инструментальная агрессия - для достижения какой-либо значимой цели;

8. жестокая агрессия - насилие и агрессия как самоцель, агрессивные действия всегда превышают действия противника, отличаются излишней жестокостью и особой злостностью: минимальный повод и максимальная жестокость. Такие люди совершают особо жестокие преступления;

9. психопатическая агрессия - жестокая и часто бессмысленная агрессия, повторяющиеся акты агрессии (агрессивный психопат, «маньяк-убийца»);

10.агрессия по мотиву групповой солидарности - агрессия или даже убийство совершается вследствие стремления следовать групповым традициям, утвердить себя в глазах своей группы, желание получить одобрение своей группы, показать свою силу, решительность, бесстрашие. Этот вид агрессии часто проявляется в группах 
подростков. Военная агрессия (действия военнослужащих в боевых условиях, убийство врага) является социально признанной и одобряемой формой агрессии по мотиву групповой (или национальной) солидарности, реализуются социальные традиции «защиты отечества», «защиты определенных идей», например, защиты демократии, защиты правопорядка и т.п.;

11.сексуальная агрессия различной степени - от сексуальной грубости до изнасилования или сексуального издевательства и убийства.

Проведенное нами в 2015 году эмпирическое исследование особенностей проявления агрессивности и склонности к психотерроризму в межличностном общении подростков [Ошибка! Источник ссылки не найден.] показало, что вероятнее всего в процессе психотеррористических действий юноши будут скорее проявлять явные формы психотерроризма (драки, ругань, угрозы и другие формы физического воздействия на жертву). Девушкам более свойственны неявные, скрытые формы (моральное и психологическое воздействие, презрительное отношение, игнорирование и т.д.). Можно с определенной долей вероятности говорить о том, что подростки, совершающие акты психотерроризма в межличностном общении, и, соответственно, не уважающие права и свободы другого человека (жертвы) и не задумывающиеся о том, какой вред они причиняют его психическому здоровью, а возможно и всей его жизни, в дальнейшем станут приверженцами экстремистской идеологии и будут более податливы для вербовщиков террористических организаций.

Нам представляются актуальными и перспективными дальнейшие исследования феноменов психотерроризма и психологического насилия в рамках социальной психологии для дополнения и расширения знаний в области проблематики деструктивной, в том числе экстремистской и террористической деятельности, разработки эффективных мер своевременной профилактики данных опасных и дестабилизирующих явлений современности и противодействия им. 
1. Кибербуллинг. Дети в информационном обществе. Выпуск 16. Сетевая агрессия. URL: http://detionline.com/journal/numbers/16. Режим доступа - свободный (на 10.07.2016).

2. Мишота В.А., Холщевников О.Г. К вопросу об экстремистских проявлениях в молодежной среде // Юриспруденция. 2010. №3. URL: http://cyberleninka.ru/article/n/kvoprosu-ob-ekstremistskih-proyavleniyah-v-molodezhnoy-srede(дата обращения: 14.10.2016).

3. Ольшанский Д.В. Психология терроризма. СПб: Питер. 2002. - 288 с.

4. Психотерроризм. URL: http://azps.ru/handbook/character/psihoterrorizm.html. Режим доступа - свободный (на 20.03.2016).

5. $\quad$ Реан А.А. Агрессия и агрессивность личности. СПб., 1996. 39 с.

6. Соловьев А. Моббинг как элемент социального конфликта. Кадровик, 2007. №12. С. 3946.

7. Чеверикина Е.А., Грязнов А.Н., Шарафиев Э.С. Индивидуальный психотерроризм в межличностном общении подростков. Казанский педагогический журнал. 2016. № 3 (116). C. 145-150.

8. Шабалин О.М. Агрессивность как комплексная характеристика индивидуальности // Психопедагогика в правоохранительных органах. 2008. №2. URL: http://cyberleninka.ru/article/n/agressivnost-kak-kompleksnaya-harakteristikaindividualnosti(дата обращения: 14.10.2016).

9. Шагако Д.С. Агрессия и насилие в контексте социальных взаимодействий // Вестник Адыгейского государственного университета. Серия 1: Регионоведение: философия, история, социология, юриспруденция, политология, культурология. 2010. №1. URL: http://cyberleninka.ru/article/n/agressiya-i-nasilie-v-kontekste-sotsialnyh-vzaimodeystviy(дата обращения: 14.10.2016).

10. Шестакова Е.Г., Дорфман Л.Я. Агрессивное поведение и агрессивность личности // Образование и наука. 2009. №7. URL: http://cyberleninka.ru/article/n/agressivnoe-povedeniei-agressivnost-lichnostci (дата обращения: 14.10.2016). 